\title{
Farmers' behavior towards risks of shallot farming: a case study in Kalisoro village, Tawangmangu district, Karanganyar regency, Central Java
}

\author{
Sriyadi ${ }^{1, *}$, and Ananti Yekti ${ }^{2}$ \\ ${ }^{1}$ Department of Agribusiness, Universitas Muhammadiyah Yogyakarta, Indonesia \\ ${ }^{2}$ Yogyakarta Agricultural Development Polytechnic (Polbangtan), Yogyakarta, Indonesia
}

\begin{abstract}
This study aimed to analyze the level of risk of shallot farming income, investigate the behavior of farmers on the risk of shallot farming, and find out the factors which could influence the farmers' Behaviors on the risk of shallot farming. This research was conducted by surveying interviews with farmers and related parties as well as field observations. The results showed that shallot farming had a fairly high variation or risk of income. The majority of farmers have adverse behavior towards the risk of shallot farming. The wider the area of land was, the older the farmer was, and the more often they failed so that as a result, the greater the farmer's aversion to risk was faced. Meanwhile, the higher the education level, the more experienced shallot farming, the greater the number of family members, and the higher the income from farming, the smaller the risk aversion of farmers was faced as well. The research results showed that the risk of shallot farming income was greater because of variations in production process. The difference of production variation due to the planting of shallots not simultaneously, so it was recommended that farmers should plant the shallots on time and simultaneously.
\end{abstract}

\section{Introduction}

Shallots come as the most widely cultivated vegetable horticulture sub-sector cultivated by farmers. According to Suriana [1], the classification of shallot plants is Kingdom: Plantae, Division: Spermatophyte, Class: Monocotyledonous, Order: Liliales, Family: Liliaceae, Genus: Allium, Species: Allium ascalonicum L. The yield of shallots varies from region to region both in terms of quality and amount of production. Regarding the statement mentioned, each region has different varieties of shallots because the farmers have to adapt to the climatic conditions, soil, and topography of each region [2]. Therefore, the shallot

*Corresponding author: sriyadi_s@yahoo.co.id 
commodity includes as a leading commodity owing to the fact that it has a very high economic value.

The national shallot productivity in 2015 reached 10.06 tons/ha [3]. However, it is still relatively low compared to the shallot productivity of other producing countries such as China, which has reached 38.43 tons per ha. Henceforth, the potential productivity of shallots in Indonesia can reach $17-20$ tons per ha through the application of standard operating procedures [4].

The success of shallot farming is not only determined by the amount of income but also by the level of efficiency and risk. The level of efficiency of farming can be seen from the ability of farmers to achieve potential income or potential gross margin. Research showed that farming can be efficient if it is able to achieve potential income or potential gross margin which is more than 75 percent $[5,6]$. Hence, the inability of farmers to achieve potential income or potential gross margin is due to the influence of farming risk.

The risk of shallot farming rises as the possibility of production and price failures due to unstable and fluctuating prices, price also as the most important risk in supply chain of shallot [32]. The risk of farming or shallot production is influenced by the use of production factors such as the use of NPK fertilizers, pesticides and labor (production risk) [7]. The existence of risk causes farmers who are essentially rational to be averter to take risks [7-9]. Research stated that interpersonal differences in risk aversion will lead to differences in decision making $[10,11]$. Thereupon, socio-economic factors influence farmer's Behaviors towards risk [5].

The existence of socio-economic factors which exist in farmers' causes the efficient farming management cannot be carried out properly. As a result, it will ultimately affect the efficiency of the use of production factors. Sabrani suggested that the level of risk aversion is closely related to the potential lost profit of forest management unit (KPH) in a unidirectional manner [12]. The greater the level of aversion to risk (failure), the greater the $(\mathrm{KPH})$ index, which means the lower the efficiency. As a matter of fact, the risk of farming affects the efficiency on the use of production factors [13].

Based on the background of study and problem formulation, the research aims to analyze the level of risk of shallot farming income, investigate the Behaviors of farmers towards the risk of shallot farming, and find out the factors that influence the farmer's Behaviors towards the risk of shallot farming.

\section{Research Method}

This research was conducted using descriptive analysis method [14-16]. The researchers undertook this research in Kalisoro Village, Tawangmangu District, which is one of the shallot centers in Karanganyar Regency, Central Java. The numbers of respondents were as many as 100 , and the data collection was conducted by means of observation and interviews with a questionnaire guide. The data processing technique used the inductive techniques, facts and events that were known concretely and were generated into a conclusion based on empirical facts at the research location. Thereupon, data analysis was carried out by qualitative descriptive methods and quantitative methods. The risk level of farming income was analyzed by the coefficient variation.

$$
K V=\frac{\sigma}{\bar{x}}
$$

Explanation:

$\mathrm{KV}=$ coefficient of variation

$\sigma \quad=$ standard deviation

$\overline{\mathrm{x}} \quad=$ average 
To find out the farmer's Behaviors towards risk of shallot farming, a quadratic utility function model approach is used.

$$
U=b_{0}+b_{1} M+b_{2} M^{2}
$$

Explanation:

$\mathrm{U}=$ utility value

$\mathrm{M}=$ acceptance obtained at the equilibrium point of the proposed alternative choices

$\mathrm{b}_{0}=$ intercept

$\mathrm{b}_{1}=$ regression coefficient

$\mathrm{b}_{2}=$ risk preference coefficient

To find out the factors that influence farmer's behavior towards risk, multiple linear regression models are used.

Explanation:

$$
b_{2}=a_{0}+\sum_{i=1}^{7} a_{i} X_{i}+\mu
$$

$\mathrm{b}_{2}=$ risk preference coefficient

$\mathrm{X}_{1}=$ land area (ha)

$\mathrm{X}_{2}=$ age (years)

$\mathrm{X}_{3}=$ education (years)

$\mathrm{X}_{4}=$ experience (years)

$\mathrm{X}_{5}=$ number of family members (person)

$\mathrm{X}_{6}=$ failure frequency (times)

$\mathrm{X}_{7}=$ farmer income (IDR/year)

$\alpha_{0}=$ intercept

$\alpha_{\mathrm{i}}=$ regression coefficient

$\mu=$ confounding variable

Testing the analytical model above using ordinary least squares (OLS) was carried out in two stages, namely (1) testing of classical assumptions, and (2) testing of model suitability [17-21]. The classical assumption test conducted in this research is multicollinearity and heteroscedasticity test; this is because the data used is in the form of one time point or cross-sectional data [30]. If the analyzed model does not contain classical assumption disturbances, then the model used to identify is the result of ordinary least squares (OLS) analysis. If there are multicollinearity and heteroscedasticity disorders, then the model has been improved so that it is free from these two disorders.

Multicollinearity test, to determine the presence of multicollinearity disorder, correlation matrix is used between independent variables, where if the correlation coefficient value between independent variables are greater than 0.8000 then there is multicollinearity disorder [21]. If there is a multicollinearity disorder in the model, it must be corrected before testing and repairing the heteroscedasticity disorder.

Heteroscedasticity test, to determine the presence of heteroscedasticity disorders contained in the Shazam data analysis program used various kinds of tests, namely; Harvey Test, Glesjer's Test, Koenker Test and Breusch-Pagan Test. If at least one of the four tests shows a heteroscedasticity disorder, then the model is corrected with the heteroscedasticity model and the analysis uses the Feasilbe Generalize Least Square (FGLS) method [20]. In improving the model for heteroscedasticity disorders, four types of heteroscedasticity models were used [22], namely; (a) model depvar (dependent variable), (b) model mult (multiplicative), (c) model stdlin (standart deviation is a linear function of exogenous variable), and (d) model varlin (variance is a linear function of exogenous variables) . From the four heteroscedasticity improvement models, one of the best (appropriate) models was chosen to be used to identify the factors that influence the risk preference coefficient. 


\section{Results and Discussion}

\subsection{Shallot Farming Risk Analysis}

To determine the risk of shallot farming income, it was conducted coefficient of variation analysis of shallot farming income. In the analysis of the coefficient of variation, it was calculated the magnitude of the coefficient of variation of farmers gaining the income from shallot farming. The analysis of the coefficient variation towards shallot farming income is presented in Table 1.

Table 1. Average, standard deviation and coefficient of variation towards shallot farming income per hectare in 2020

\begin{tabular}{|l|c|}
\hline \multicolumn{1}{|c|}{ Farming Income } & Shallots \\
\hline Income (IDR) & $69,500,000$ \\
\hline Standard Deviation & $35,400,700$ \\
\hline Coefficient of Variation & 0.509 \\
\hline
\end{tabular}

The results showed that shallot farming had a fairly high-income variation with the lowest income of IDR 61,500,000 per hectare and the highest of IDR 125,500,000 per hectare. From the results mentioned, it is in accordance with previous research [9, 23]. Research explains that the level of risk to onion farming is quite high [24]. Research shows that the risk level of onion farming is also quite high [7]. Other studies also show that the level of risk in shallot farming also tends to be quite high [25].

Two variables which had directly affected the income of farmers obtained from their farming were production and price. The risk of shallot farming income which might be endured by farmers was greater due to variations in production. Besides, the lowest production variation was $8,150 \mathrm{~kg}$ per hectare, and the highest part was $12,560 \mathrm{~kg}$ per hectare while the lowest price variation was IDR 16,500 per kilogram and the highest price was IDR 20,000, - per kilogram. Thereupon, from the results mentioned, this different production variation was due to farmers not planting shallots simultaneously.

The difference in planting time caused the differences in growth time and also differences in harvest time which ultimately caused the differences in the resulting production. As a result, the growth of shallots was strongly influenced by weather and climate, for example, farmers who plant shallots in the middle of the rainy season around December in which at that month, the rainfall was quite high. Of course, it would affect low production. Regarding the statement mentioned, it was different from farmers who plant shallots at the end of the rainy season which would certainly produce better production owing to the fact that at the end of the rainy season, there was less rainfall or rainfall low. To sum up, by looking at the variety of shallot production, it showed that the variation in shallot income was due to differences in the quality produced by farmers with different qualities causing different prices and different income received.

\subsection{Farmers' Behaviors against Risk}

To determine the farmer's Behaviors towards the risk of shallot farming, a quadratic utility function was used. The estimation of the utility function of each farmer was carried out based on the Bernoulli-Morgenstern principle which was refined with neutral probability (50:50) and the procedures described in the research method.

From the utility function of each farmer in shallot farming, the coefficient of determination $\left(\mathrm{R}^{2}\right)$ was the lowest 0.927 and the highest one was 0.999. Based on the statement mentioned, this showed that the variation in the utility value of shallot farming 
was caused by variations in the acceptance of shallot farming by 92.70 percent while the 7.30 percent was caused by variations in other factors which were not included in the model for farmers with the lowest coefficient of determination $\left(\mathrm{R}^{2}\right)$. In addition, the farmers with the highest coefficient of determination $\left(\mathrm{R}^{2}\right)$ indicated that the variation in the utility value of shallot farming was caused by variations in shallot farming revenues of 99.90 percent while the 0.10 percent was caused by variations in other factors which were not included in the model. Besides, the value of F-Count came as the lowest value with the total value of 65.052 and the highest value was 950.500 .

Table 2. Distribution of shallot farmers' behavior towards risk of farming business in 2020

\begin{tabular}{|l|r|r|}
\hline \multicolumn{1}{|c|}{ Behaviors } & Total & Percentage \% \\
\hline Averter & 94 & 94 \\
\hline Neutral & 6 & 6 \\
\hline Lover & 0 & 0 \\
\hline$\left(\mathrm{R}^{2}\right)$ Lowest & \multicolumn{2}{|c|}{0.927} \\
\hline$\left(\mathrm{R}^{2}\right)$ Highest & \multicolumn{2}{|c|}{65.052} \\
\hline Lowest F-count & \multicolumn{2}{|c}{950.500} \\
\hline Highest F-count & \multicolumn{2}{|c}{}
\end{tabular}

Based on Table 2, it showed that out of 100 farmers, 94 farmers or 94 percent of farmers had a negative and significant risk coefficient $\left(b_{2}\right)$ meaning that farmers behaved avertedly towards the risk of shallot farming. Besides, 4 farmers had a negative risk coefficient $\left(b_{2}\right)$, and 2 farmers had a risk coefficient $\left(b_{2}\right)$ which was positive but not significant. From the statement mentioned, the farmers behaved neutrally towards the risk of shallot farming, and there was no farmer who dared to risk the shallot farming. The results showed that most of the farmers behaved avertedly towards the risk of shallot farming. This could also be seen from the average risk coefficient value $\left(b_{2}\right)$ which showed that the value was $-0.157 \mathrm{E}-06$. of shallot farming out of $-0.157 \mathrm{E}-06$. Previous studies explain that the majority of farmers are risk averse [7, 9, and 11].

In addition, most farming households were faced with a central economic dilemma [26]. The life of farmers in rural areas was quite close to the subsistence limit, and they always experienced weather uncertainty so that farmers did not have the opportunity to apply the maximum profit calculation in farming. The results also show that farmers will always try to avoid failure and do not get big profits by taking risks. Such behavior is called safety first or putting safety first which comes a characteristic of most farmers.

Furthermore, farmers in cultivating shallot farming had the motivation to obtain higher income because shallot produced fast and the price was quite high. However, most of the farmers (90 percent of respondent) had not dared to cultivate shallots on a large scale considering the risks which they will face are quite large such as pests and diseases or unstable price fluctuations. These could impact the farmers who had small capital or limited capital. Besides, a small number of farmers (11 percent of respondent) had dared to cultivate shallots on a large scale because they were farmers who had large capital and were speculative. For small farmers or farmers with small capital, when harvest time came, inevitably all the results should be sold, and both the price was high or low. As a reason, the farmers did not have a budget to meet their daily needs. Meanwhile, for farmers who had large capital when harvest time came. When the price was good or the yield was high, all of the shallots were sold. However, if the price was low, they usually did not sell immediately. Therefore, those shallots were sold when the price was high, and usually the farmers still had a budget to meet their needs.

Farmers in the efforts to farm shallots with intercropping and intercropping systems, this is done to avoid the risk of failure. Their hope if they fail in trying shallots will work 
on other crops. Out of 100 farmers 60 percent do garlic planting pattern - carrot - shallot carrot. Shallot planting will be done in November and is expected to be harvested in early February, when the shallots are 45 days old around mid-December in between shallots planted with carrots. Shallots will be harvested after 105 days, by then the carrot plant has been 50 days old and the carrot plant is expected to harvest in March.

\subsection{Socio-Economic Factors Affecting Farmers' Behaviors towards Risk}

Socio-economic variables which were assumed to influence farmer's behavior towards risk included land area, age, education, experience, number of family members, frequency of failure during the last five years, and income from farming for one year. In this case the dependent variable used was the risk coefficient $\left(b_{2}\right)$ as the results of the analysis towards the quadratic utility function. Following this, there were seven variables which were considered to influence farmers' behavior towards risk. To analyze the factors which could influence farmers' behavior towards risk, a multiple linear equation model was used which the results were presented in Table 3. Based on Table 3, it showed that of the seven independent variables, there were three independent variables, namely age, education and farmers' income which had a significant effect on the dependent variable, namely the risk coefficient as a measure of farmer's Behaviors towards farming risk.

The following stage aimed to see whether there were deviations from the classical assumptions of the multiple linear regression model or not, by detecting the presence of multicollinearity and heteroscedasticity. Multicollinearity defined that there was a perfect or definite linear relationship between some or all of the variables which explained the regression model. To detect whether there was a multicollinearity problem in the estimator model, correlation coefficient indicators were used between independent variables. Therefore, the results of the analysis showed that the correlation coefficient between the independent variables was quite small, so it could be concluded that in the multiple linear regression model used for analysis, there was no multicollinearity problem.

Table 3. Regression coefficient and t-count function of shallot farmers' Behaviors on risk in 2020

\begin{tabular}{|l|c|c|}
\hline \multicolumn{1}{|c|}{ Independent Variable } & Regression Coefficient & T-Count \\
\hline Intercept & $0.955 \mathrm{E}-05^{* * *}$ & 12.540 \\
\hline Land area $\left(\mathrm{X}_{1}\right)$ & $-0.675 \mathrm{E}-10 \mathrm{NS}$ & -0.875 \\
\hline Farmers' Age $\left(\mathrm{X}_{2}\right)$ & $-0.275 \mathrm{E}-07 * *$ & -2.223 \\
\hline Farmers' Education $\left(\mathrm{X}_{3}\right)$ & $0.665 \mathrm{E}-08^{* *}$ & 2.254 \\
\hline Farmers' Experience $\left(\mathrm{X}_{4}\right)$ & $0.290 \mathrm{E}-07 \mathrm{NS}$ & 1.215 \\
\hline Number of Family Members $\left(\mathrm{X}_{5}\right)$ & $0.675 \mathrm{E}-08 \mathrm{NS}$ & 0.252 \\
\hline Failure Frequency $\left(\mathrm{X}_{6}\right)$ & $-0222 \mathrm{E}-06 \mathrm{NS}$ & -0.444 \\
\hline Farmers' income $\left(\mathrm{X}_{7}\right)$ & $0.275 \mathrm{E}-15^{* *}$ & 2.275 \\
\hline Coefficient of Determination $\left(\mathrm{R}^{2}\right)$ & 0.790 & \\
\hline F-count & $9.523 * * *$ & \\
\hline DW & 1.811 & \\
\hline
\end{tabular}

\footnotetext{
Explanation:

- *** : significant on $\alpha: 1 \%$

$* *$ : significant on $\alpha: 5 \%$

* : significant on $\alpha: 10 \%$

NS : not significant on $\alpha: 10 \%$
} 
- T-table (with $\mathrm{df}=\infty$ ) towards $\alpha: 1 \%=2.576 ; \alpha: 5 \%=1.960$;

and $\alpha: 10 \%=1.645$

- F-table, on $\alpha: 1 \%=2.510 ; \alpha: 5 \%=1.940$; and $\alpha: 10 \%=1.670$

Table 4. Regression analysis between risk coefficients and seven independent variables which have eliminated the effect of heteroscedasticity in 2020

\begin{tabular}{|c|c|c|c|c|c|}
\hline \multirow[t]{2}{*}{ Independent Var } & \multirow{2}{*}{$\begin{array}{c}\begin{array}{c}\text { Coef. } \\
\text { Regression }\end{array} \\
\text { OLS }\end{array}$} & \multicolumn{4}{|c|}{ Coef. Heteroscedasticity-Free Regression } \\
\hline & & DEPVAR & MULT & STDLIN & VARLIN \\
\hline Intercept & $\begin{array}{r}0.95 \mathrm{E}-05 * * * \\
(12.540) \\
\end{array}$ & $\begin{array}{r}0.72 \mathrm{E}-05^{* * *} \\
(15.45) \\
\end{array}$ & $\begin{array}{r}0.67 \mathrm{E}-05 \mathrm{NS} \\
(0.874) \\
\end{array}$ & $\begin{array}{r}0.82 \mathrm{E}-05 \mathrm{NS} \\
(0.578) \\
\end{array}$ & $\begin{array}{r}0.16 \mathrm{E}-06^{* * *} \\
(3.575) \\
\end{array}$ \\
\hline Land Area $\left(\mathrm{X}_{1}\right)$ & $\begin{array}{r}-0.67 \mathrm{E}-10 \mathrm{NS} \\
(-0.875) \\
\end{array}$ & $\begin{array}{r}-0.63 \mathrm{E}-10 * * * \\
(-12.27) \\
\end{array}$ & $\begin{array}{r}-0.73 \mathrm{E}-10^{*} \\
(-1.767) \\
\end{array}$ & $\begin{array}{r}-0.46 \mathrm{E}-10 \mathrm{NS} \\
(-1.337) \\
\end{array}$ & $\begin{array}{r}-0.29 \mathrm{E}-13 \mathrm{NS} \\
(-0.123) \\
\end{array}$ \\
\hline Farmers' Age $\left(\mathrm{X}_{2}\right)$ & $\begin{array}{r}-0.27 \mathrm{E}-07 * * \\
(-2.223) \\
\end{array}$ & $\begin{array}{r}-0.37 \mathrm{E}-07 * * * \\
(-12.67) \\
\end{array}$ & $\begin{array}{r}-0.14 \mathrm{E}-09 \mathrm{NS} \\
(-1.152) \\
\end{array}$ & $\begin{array}{r}-0.33 \mathrm{E}-09 \mathrm{NS} \\
(-0.875) \\
\end{array}$ & $\begin{array}{r}-0.15 \mathrm{E}-08^{*} \\
(-1.832) \\
\end{array}$ \\
\hline $\begin{array}{l}\text { Farmers' Education } \\
\left(\mathrm{X}_{3}\right)\end{array}$ & $\begin{array}{r}0.66 \mathrm{E}-08 * * \\
(2,254)\end{array}$ & $\begin{array}{r}0,38 \mathrm{E}-08 * * * \\
(12,95)\end{array}$ & $\begin{array}{r}0,11 \mathrm{E}-08 * * * \\
(2,953)\end{array}$ & $\begin{array}{r}0,13 \mathrm{E}-08 \mathrm{NS} \\
(1,274)\end{array}$ & $\begin{array}{r}0,45 \mathrm{E}-08 * * * \\
(2,777)\end{array}$ \\
\hline $\begin{array}{l}\text { Farmers' Experience } \\
\left(\mathrm{X}_{4}\right)\end{array}$ & $\begin{array}{r}0,29 \mathrm{E}-07 \mathrm{NS} \\
(1.215)\end{array}$ & $\begin{array}{r}0.27 \mathrm{E}-07 * * * \\
(8.87)\end{array}$ & $\begin{array}{r}0.23 \mathrm{E}-09 \mathrm{NS} \\
(0.675)\end{array}$ & $\begin{array}{r}0.46 \mathrm{E}-09 \mathrm{NS} \\
(1.245)\end{array}$ & $\begin{array}{r}0.49 \mathrm{E}-09 \mathrm{NS} \\
(0.275)\end{array}$ \\
\hline $\begin{array}{l}\text { Number of Family } \\
\text { Members }\left(\mathrm{X}_{5}\right)\end{array}$ & $\begin{array}{r}0.67 \mathrm{E}-08 \mathrm{NS} \\
(0.252)\end{array}$ & $\begin{array}{r}0.77 \mathrm{E}-08 * * * \\
(11.35)\end{array}$ & $\begin{array}{r}0.57 \mathrm{E}-08 \mathrm{NS} \\
(0.775)\end{array}$ & $\begin{array}{r}0.13 \mathrm{E}-08 \mathrm{NS} \\
(0.550)\end{array}$ & $\begin{array}{r}0.89 \mathrm{E}-08 \mathrm{NS} \\
(1.377)\end{array}$ \\
\hline $\begin{array}{l}\text { Failure Frequency } \\
\left(\mathrm{X}_{6}\right)\end{array}$ & $\begin{array}{r}-0.22 \mathrm{E}-06 \mathrm{NS} \\
(-0.444)\end{array}$ & $\begin{array}{r}-0.12 \mathrm{E}-06^{* * *} \\
(-11.81) \\
\end{array}$ & $\begin{array}{r}-0.81 \mathrm{E}-09 \mathrm{NS} \\
(-0.987)\end{array}$ & $\begin{array}{r}-0.16 \mathrm{E}-09 \mathrm{NS} \\
(-0.145) \\
\end{array}$ & $\begin{array}{r}-0.18 \mathrm{E}-07 * \\
(-1.878) \\
\end{array}$ \\
\hline $\begin{array}{l}\text { Farmers' income } \\
\left(\mathrm{X}_{7}\right)\end{array}$ & $\begin{array}{r}0.27 \mathrm{E}-15 * * \\
(2.275)\end{array}$ & $\begin{array}{r}0.22 \mathrm{E}-15 * * * \\
(11.75)\end{array}$ & $\begin{array}{r}0.73 \mathrm{E}-09 * * * \\
(3.340)\end{array}$ & $\begin{array}{r}0.68 \mathrm{E}-09 \mathrm{NS} \\
(1.295)\end{array}$ & $\begin{array}{r}0.75 \mathrm{E}-09^{*} \\
(1.756)\end{array}$ \\
\hline $\mathrm{R}^{2}$ & 0.790 & 0.790 & 0.790 & 0.790 & 0.790 \\
\hline F-Count/LR & $9.523 * * *$ & $26.356 * * *$ & $26.356 * * *$ & $26.356^{* * * *}$ & $26.356 * * *$ \\
\hline
\end{tabular}

Explanation:

- OLS : Ordinary least square

- Depvar : Heteroscedasticity improvement with dependent variable

- Mult : Heteroscedasticity improvement with multiplicative

- Stdlin : Heteroscedasticity improvement with standard deviation which is a linear function of exogenous variable

- Varlin : Heteroscedasticity improvement with variance which is a linear

Function of exogenous variable

- *** : significant on $\alpha: 1 \%$

** : significant on $\alpha: 5 \%$

* : significant on $\alpha: 10 \%$

NS : not significant on $\alpha: 10 \%$

- The number in brackets is t-count

- T-table (with $\mathrm{df}=\infty$ ) towards $\alpha: 1 \%=2,576 ; \alpha: 5 \%=1,960$; and $\alpha: 10 \%=1,645$

- F-table, on $\alpha: 1 \%=2,510 ; \alpha: 5 \%=1,940 ;$ and $\alpha: 10 \%=1,670$

- Chi-Square, on $\alpha: 1 \%=20,090 ; \alpha: 5 \%=15,510$;

and $\alpha: 10 \%=13,360$

Heteroscedasticity occurred if the variance of each element on the disturbance ui was not constant. The problem of heteroscedasticity often occurred in cross-sectional data [27]. In order to detect heteroscedasticity problems, this study used the Harvey Test, Glesjer's Test, Koenker Test and Breusch-Pagan Test methods. The results of the analysis showed that there was a heteroscedasticity problem that occurred in the estimator model. To eliminate the effect of heteroscedasticity, an improved model was also used, namely the 
depvar model (improvement of heteroscedasticity with the dependent variable), the mult model (improvement of heteroscedasticity with multiplicative), the stdlin model (improvement of heteroscedasticity with standard deviation is a linear function of exogenous variable), and the varlin model (improvement of heteroscedasticity with standard deviation is a linear function of exogenous variable). Accordingly, the heteroscedasticity with variance was a linear function of exogenous variable which the results were presented in Table 4.

Based on the results of the analysis in Table 4, it was known that the heteroscedasticity model had a coefficient of determination $\left(R^{2}\right)$ of 0.79 . From the statement mentioned, it presented that as much as 79.00 percent of the variation in the value of the risk coefficient or farmer behavior towards risk was explained by variations in land area, age, education, experience, number of family members, frequency of failure during the last five years, and income from farming, while 21.00 percent was explained by other variables that determined but were not included in the model.

The calculation results obtained that likelihood ratio (LR) value of 26.356 is greater than the chi-square value chi-square ( $\chi^{2}$-tabel of 20.090). As a result, the independent variables jointly had a significant effect on the dependent variable. In other words, farmers' behavior towards risk was influenced by the socio-economic characteristics of farmers altogether which included land area, age, education, experience, number of family members, frequency of failure during the last five years, and income from farming.

Based on the Depvar model (heteroscedasticity improvement with the dependent variable), it was known that all independent variables had a significant partial effect on the dependent variable. Based on the results of the analysis of socio-economic factors that influenced the behavior of farmers on the risk of shallot farming (Table 4), those can be described as follows:

\subsubsection{Land Area}

Farmers had a relatively narrow land area which was an average of 0.1860 hectares. Based on Table 4, it showed that the land area had a regression coefficient which was negative and significant meaning that by increasing the land area, it could significantly reduce the risk coefficient of ceteris paribus. In other words, the wider the farm land, the more averter the farmers were to the risk of failure. These findings were in accordance with several studies conducted by $[6,12,28,29]$, but it had contradicted results with a study carried out by [30].

For farmers, the decision to plant shallots was actually a risky decision due to the uncertainty factor. If the narrow land was already risky, especially with a large area, the risk of failure was even greater. In addition to the uncertainty factor, the risk of this failure was also due to erratic seasons or rains, for example, planting shallots in the dry season where there should be no rain in fact there was rain affecting the growth and production of shallots.

\subsubsection{Farmers' Age}

The average age of farmers was 35 years with the oldest 65 years old and the youngest 28 years old. Age had a regression coefficient which was negative and significant meaning that increasing age could significantly reduce the risk coefficient of ceteris paribus. In other words, the older the farmer, the more averter he was to the risk of failure while the younger the farmer the less averse he was to the risk of failure.

This issue was understandable because there were some farmers who were older even though they had more experience and skills but were usually more conservative and tire more easily. Younger farmers, although lacking in experience and skills, behaved more 
progressively towards new innovations and were physically stronger. Hence, this progressive nature tended to shape the behavior of young farmers who had willingness to take risks more. Regarding the statement mentioned, it was shown by some young farmers who started to dare to change in the use of production factors, for example, they were no longer using chemical fertilizers and switching to organic fertilizers, including they had started to reduce the use of chemical pesticides. Also, they could use chemical pesticides if they would do considered necessary because there were pests and diseases. The farmers' habit which has been going on so far was to always spray using chemical pesticides once a week whether there were pests or diseases or not. These findings were in line with several previous studies conducted by some experts, and those were $[6,9,12,28-30]$ who had same results although in the research of [6] and [28], age was not significant. However, the trend was the same, namely age was inversely proportional to the risk coefficient. Consequently, this result contradicted with the results of [24] study which showed that younger farmers were more risk averse than older farmers.

\subsubsection{Farmers' Education Background}

The length of time that farmers had taken formal education was 13 years on average and had a distribution of 9 to 21 years. On average, farmers had completed Junior High School (SLTP). Besides, farmer's education variable had a positive and significant regression coefficient. As a result with increasing education, it could significantly increase the risk coefficient by assuming other factors remain. In other words, the higher the level of education, farmers were more willing to take risks. In regards to the statement mentioned, this could happen because the average farmer had a High School education (SMA), and usually farmers with higher education were willing to take risks. Thereupon, these results were consistent with the results of research carried out by $[9,28,29]$ which showed that farmers with higher education behaved more willingly towards risk than farmers with lower education.

\subsubsection{Farmers' Experiences}

Farmers' experiences in farming shallots vared widely. The experience of farmers in shallot farming varied from 9 years to 17 years with an average of 12 years. The experience of shallot farming farmers had a positive and significant regression coefficient. As a reason, with the increase in shallot farming experience, the risk coefficient of ceteris paribus could significantly increase. In other words, the more mature the experience of farmers in farming shallots, the less risk averse farmers could be. Thereupon, these findings were consistent with several previous studies conducted by [6, 12, 28-31].

The knowledge and skills of farmers in farming shallots were obtained from their experience and observations, both the experience gained from generation to generation and the experience gained from the surrounding environment. Farmers who already had mature experience and were willing to learn from experience, were quite skilled and knew the possibility of something happening as a result of the decisions they made, for example regarding prices and productivity. From the statement mentioned, this was shown by some farmers who were members of farmer groups. Before deciding to cultivate the shallots, they always considered the events or experiences of previous years. In addition, they also conducted surveys to other areas that cultivated similar commodities because if other regions also worked on the same commodity, it was certain that the price when the harvest would fall so that the alternative crops were needed. Therefore, the experience of failure in the past can be a very valuable lesson for farmers, and farmers will try to anticipate so that similar failures do not occur. 


\subsubsection{Number of Family Members}

The number of family members had a distribution between 1 until 3, and the average farmer had 2 family members. The variable number of family members had an elasticity that was positive and significant, meaning that with increasing family members, it could significantly increase the risk coefficient assuming other factors remain. From the statement mentioned, the more the number of family members, the smaller the farmer's aversion to risk.

Regarding the issues occurred; the number of family members was closely related to the availability of labor. It should be noted that shallot farming required a lot of manpower. Most of the farmers used the labor in the family for all activities started from seed preparation, tillage, planting, weeding, fertilizing, watering, and harvesting to post-harvest. In addition, the results of this study also showed that the large number of family members required the head of the family to work harder so that the results obtained were high. As a result, they could meet the needs of the family. From the statement mentioned, it was an encouragement for farmers to behave more willingly to take risks. Accordingly, these results were in line with the findings of [6, 28-31], but those showed the contradicted results from research [24].

\subsubsection{Failure Frequency}

The failure of shallot farming in most farmers was due to the uncertainty of the season which caused the emergence of pests and diseases. In addition, the failure to farm shallots was also caused by the unstable price factor plus the high cost of farming shallots. The frequency of failure during the last five years had a distribution between 0 to 1 time, and the average was 0.06 times. Besides, the elasticity of the failure frequency of shallot farming had a negative and significant value. As a result, by increasing the frequency of failure, it could significantly reduce the risk coefficient assuming other factors remain. In other words, the greater the frequency of failure, the greater the farmer's aversion to risk. Hence, this result was in accordance with the results of [28] research which showed that the frequency of failure was inversely proportional to the risk coefficient, in other words, the greater the frequency of failure, the more averter farmers are to risk.

\subsubsection{Farmers' Income}

Farmers' income from farming for a year ranged from IDR 25,000,000 to IDR 145,000,000 with an average income of IDR $82,500,000$ per year. Most of this income was obtained from shallot farming (twice) and polowijo. Farmers' income from farming for a year had a positive and significant elasticity. As a result, with increasing income from farming, it could significantly increase the risk coefficient ceteris paribus. In other words, the increase in income from farming would be able to lead to less risk aversion by farmers. The results of this study were in line with several previous studies conducted by [9, 24, and 29], it was not significant, but the tendency was the same, for example, the income was directly proportional to the coefficient of income risk. However, the results of this study showed the contradictive results with a study carried out by [6].

Regarding the results mentioned, this was reasonable because the main motivation of farmers in farming shallots was to obtain high income. Besides, shallot farming required high costs, so that high income or income was required. There were even some farmers who had high income or capital dared to cultivate the shallots on a larger scale. They were not afraid to face the risk of failure because they still had a budget for their daily needs. 


\section{Conclusions and Policy Implication}

\subsection{Conclusion}

The research results showed that shallot farming had a fairly high variation or risk of income. Two variables that directly affected the income of farmers obtained from their farming were production and price. The risk of shallot farming income which might be cultivated by farmers was greater due to variations in production.

By using quadratic utility function analysis from 100 sample farmers, the results were obtained that 94 percent of sample farmers had adverse behavior towards the risk of shallot farming, 6 percent of sample farmers had neutral behavior towards the risk of shallot farming and none of the farmers lowed to risk the shallot farming.

Socio-economic factors which significantly influenced the behavior of farmers on the risk of shallot farming were land area, age, education, experience of farming shallots, number of family members, frequency of failure to farm shallots during the last five years, and income from farming. From this research results, the area of land, age of the farmer and the frequency of failure to farm shallots during the last five years had a negative effect while education, experience of farming shallots, number of family members, and income from farming had a positive influence. To sum up, the wider the area of land, the older the farmer and the more often they fail, the greater the farmer's aversion to risk. Meanwhile, the higher the education level, the more experienced shallot farming can be, the greater the number of family members, and the higher the income from farming, the smaller the risk aversion of farmers.

\subsection{Policy Implications}

The results showed that the risk of shallot farming income which may be cultivated by farmers is greater due to variations in production. This difference in production variation is also due to the fact that the planting of shallots is not simultaneous. Besides, the farmers who cultivate shallots on time will obtain optimal results while those who cultivate not on time will obtain non-optimal results. Thereupon, this situation requires a government policy regarding the right time for planting shallots. Through counseling, farmers are given an understanding of the right time to plant shallots.

\section{References}

1. Suriana, N., Bawang Bawa Untung Budidaya Bawang Merah dan Bawang Putih. Yogyakarta: Cahaya Atma Pustaka, (2011).

2. Pranata, A., \& Umam, A. T., Pengaruh Harga Bawang Merah Terhadap Produksi Bawang Merah di Jawa Tengah. JEJAK, 8(1), (2015).

3. Kementerian Pertanian, Outlook Bawang Merah 2016. Pusat Data dan Sistem Informasi Pertanian Kementerian Pertanian, 2, (2016).

4. BAPPENAS, Rencana pembangunan jangka menengah bidang pangan dan pertanian 2015-2019, 1-419, (2015).

5. Dillon, J. L., \& Scandizzo, P. L., Risk Behaviors of Subsistence Farmers in Northeast Brazil: A Sampling Approach. American Journal of Agricultural Economics, 60(3), 425-435, (1978).

6. Rusmadi, Pengaruh Sikap Petani Terhadap Risiko dalam Upaya Pengembangan Komoditas Kedelai (Studi Kasus di Desa Ngabar Kabupaten Pasuruan, Jawa Timur). 
Universitas Gadjah Mada, (1992).

7. Mutisari, R., \& Meitasari, D., Analisis Risiko Produksi Usahatani Bawang Merah di Kota Batu. Jurnal Ekonomi Pertanian dan Agribisnis, 3(3), 655-662, (2019).

8. Mufriantie, F., \& Suhatmini, Analisis risiko berbagai pola tanam pada lahan sawah di Kecamatan Cangkringan Kabupaten Sleman. Universitas Gadjah Mada, (2014).

9. Lawalata, M., Risiko Usahatani Bawang Merah di Kabupaten Karanganyar. JURNAL AGRICA, 10(2), 56, (2017).

10. Binswanger, Empirical Estimation and Use of Risk Preferences: Discussion. American Journal Of Agricultural Economics. Vol 64 Issue 2. Page 391-393, (1982).

11. Erny, Darwanto, D. H., Masyhuri, \& Waluyati, L. R., Farmer's behavior towards lembah palu shallot farm risks in central sulawesi, Indonesia. EurAsian Journal of BioSciences, 13(2), 931-936, (2019).

12. Sabrani, M., Perilaku petani ternak domba dalam alokasi sumber daya :: Studi kasus di Mijen dan Klepu, Jawa Tengah. Universitas Gadjah Mada, (1989).

13. Sriyadi, Risiko Usahatani. Yogyakarta: Lembaga Penelitian, Publikasi dan Pengabdian Masyarakat (LP3M) UMY, (2014).

14. Gulo, W, Metodologi penelitian. Jakarta: Gramedia Widiasarana Indonesia, (2012).

15. Nasution, S., Metode Research (penelitian ilmiah). Jakarta: Bumi Aksara, (2010).

16. Sugiyono, Metode penelitian pendidikan:(pendekatan kuantitatif, kualitatif dan $R \&$ D). Bandung: Alfabeta, (2014).

17. Pindyck, R.S. and D.L. Rubinfeld, Econometric Models and Economic Fore Casts. Mc Graw-Hill. New York, (1991).

18. Pindyck, R.S. and D.L. Rubinfeld, Microeconomics. Fifth Edition. Prentice-Hall International. Inc., (1998).

19. Maddala.G.S., Introduction to Econometric. Seconds Eds, Prentice Hall International, Inc. New Jersey, (1992).

20. Greene, W.H., Econometric Analysis, Second Edition. Macmillan Publishing Company. New York, (1993).

21. Gujarati, D., Ekonometrika Dasar. Erlangga Jakarta, (1997).

22. White, K.J., S.D. Whistler., S.A. Haun. Shazam Econometrics Computer Program: User's Reference Manual Version 6.2. Mc Graw-Hill Book Company, (1990).

23. Fauzan, M., Pendapatan, Risiko dan Efisiensi Ekonomi Usahatani Bawang Merah di Kabupaten Karanganyar. AGRARIS: Journal of Agribusiness and Rural Development Research, 2(2), 107-117, (2016).

24. Astuti, L. T. W., Daryanto, A., Syaukat, Y., \& Daryanto, H. K., Analisis Resiko Produksi Usahatani Bawang Merah pada Musim Kering dan Musim Hujan di Kabupaten Brebes. Jurnal Ekonomi Pertanian dan Agribisnis, 3(4), 840-852, (2019).

25. Ghozali, M. R., \& Wibowo, R., Analisis Risiko Produksi Usahatani Bawang Merah di Desa Petak Kecamatan Bagor Kabupaten Nganjuk. Jurnal Ekonomi Pertanian dan Agribisnis, 3(2), 294-310, (2019).

26. Scott, J.C., "The Economy of Peasant Rebellion and Subsistence in Sutheast Asia". Yale University Press. London, (1997).

27. Gujarati, D. Ekonometrika Dasar. Erlangga Jakarta, (1997).

28. Istiyanti, E. "Analisis Pendapatan dan Perilaku Petani Terhadap Risiko dalam Pengembangan Usahatani Bawang Merah (Studi Kasus di Kecamatan Panjatan Kabupaten Kulon Progo)". Thesis Ekonomi Pertanian Program Pasca Sarjana UGM, 
(1999).

29. Pujiharto, \& Wahyuni, S. Analisis Perilaku Petani Terhadap Risiko Usahatani Sayuran Dataran Tinggi : Penerapan Moscardi and De Janvry Model. AGRITECH: Jurnal IlmuIlmu Pertanian, 19(1), 65-73, (2017).

30. Damaijati, E. "Studi Tentang Perilaku Petani Terhadap Risiko Serta Hubungannya dengan Pengambilan Kredit pada Usahatani Kedelai". Thesis Ekonomi Pertanian Program Pasca Sarjana UGM Yogyakarta, (1992).

31. Juarini, "Perilaku Ekonomi Petani terhadap Risiko Usahatani di Lahan Pantai Kabupaten Kulon Progo". Disertasi Ekonomi Pertanian Pasca sarjana UGM. Yogyakarta, (2003).

32. Susanawati and M. Fauzan, Risk of shallot supply chain: An Analytical Hierarchy Process (AHP) model in Brebes Java, Indonesia, Int. J. Supply Chain Manag. 8, 124 (2019). 